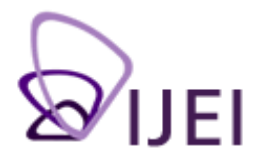

International

Journal for

Educational Integrity

\title{
An exploration of the role of Canadian academic libraries in promoting academic integrity*
}

\author{
Lorie Kloda and Karen Nicholson \\ McGill University, Montreal, Canada
}

Keywords: Academic integrity, Canada, librarians, plagiarism, text-matching software, universities

\begin{abstract}
The incidence of student plagiarism at Canadian universities and colleges is cause for concern. As a result, Canadian universities are increasingly using text-matching software such as Turnitin to address the problem of cut-and-paste plagiarism. An exploratory survey was conducted at Canadian research-intensive universities subscribing to Turnitin to examine the role of librarians in educating students and faculty about academic integrity. Results indicate that librarians at these institutions are actively involved in promoting academic integrity and deterring plagiarism. At most institutions surveyed, discussions of academic integrity and the ethical use of information are included in library workshops and library instructional materials. These results, while preliminary, are an important first step to encourage libraries to consider their role within universities for promoting academic integrity.
\end{abstract}

*This is a revised version of a paper presented at LILAC 2005: Librarians Information Literacy Annual Conference, Imperial College, London, April 4-6, 2005.

\section{Background}

According to a 2003 online survey of 16,000 undergraduates at 11 Canadian universities conducted by Center for Academic Integrity founder Donald McCabe, one third of Canadian university students have plagiarised at least once before graduation and one in five undergraduates admitted to other serious breaches of academic integrity. In the same study, $5 \%$ of students admitted submitting an essay they had purchased online as their own (Sokoloff, 2003). At top-ranked University of Toronto, from 2001 to 2002, Internet plagiarism increased from approximately 55\% of all reported academic offences in the Faculty of Arts and Sciences to 99\% (Wahl, 2002).

Faced with these statistics, Canadian universities are increasingly using textmatching software such as Turnitin ${ }^{1}$ as a means of preventing and detecting plagiarism. The number of Canadian universities and colleges that currently subscribe to Turnitin is, according to one estimate, as high as 28 (Brown, 2004) and one provincial university consortium, the Council of Ontario Universities, has negotiated an agreement with iParadigms, creator of Turnitin, for all its member institutions (Goel, 2002). In fact, the first Canadian conference on academic integrity, the Ontario Universities Conference on Academic Integrity, held in Ontario in August 2003, featured keynote speaker John M. Barrie, president and founder of iParadigms, and included a forum on the effectiveness of dealing with plagiarism using Turnitin.

In the same year, McGill University, located in Montreal, Quebec, undertook a limited trial of text-matching software in specific undergraduate courses. Despite the fact that use of Turnitin had become a relatively common practice in Canadian universities, the McGill trial received considerable attention from student, national and international

The International Journal for Educational Integrity is available online at: http://www.ojs.unisa.edu.au/journals/index.php/lJEl/

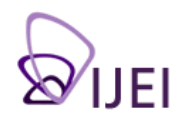


media after a student refused to submit his work to the service and successfully challenged the university's policy requiring the use of Turnitin (Brown, 2004; Churchill, 2004).

Student and faculty reactions to the software on the McGill campus have been mixed. Despite the continuing debate however, two indisputably positive outcomes of the Turnitin trial have been increased campus awareness of the importance of academic integrity and discussion of the use of alternative methods of deterring plagiarism. Collaborative initiatives involving key stakeholders, including the University's administration, teaching and learning services, libraries and student advocacy groups, are being pursued to promote academic integrity at McGill. These activities provided the impetus for our research as we asked ourselves if Turnitin has had the same impact at other Canadian research-intensive universities. What roles do librarians at those institutions play in promoting academic integrity and deterring plagiarism?

\section{Literature review}

We limited our review of the literature on plagiarism and academic integrity to texts which discuss the role of librarians in promoting academic integrity as well as those that examine the impact of text-matching software, such as Turnitin, on collaborative initiatives between librarians and other campus units to educate students about the ethical use of information.

As information literacy experts, librarians believe they are particularly well-suited to play a strong lead in deterring plagiarism and promoting academic integrity on campus (Burke, 2004; Lampert, 2004; Wood, 2004). Librarian interest in the issue of plagiarism is evidenced by the sizable amount of discussion and research published in the professional and scholarly literature since 1998 (Arp \& Woodard, 2002). However, the activities librarians undertake in the promotion of academic integrity and deterrence of plagiarism on campus have changed considerably over the past seven years. Prior to 2000 , librarians described their role in the fight against plagiarism as that of a 'plagiarism buster' charged with assisting faculty in tracking down plagiarised text, teaching effective search strategies for detecting plagiarism, and maintaining lists of term paper mills ${ }^{2}$ (Arp \& Woodard, 2002; Burke, 2004; Oliphant, 2002; Wood, 2004). In more recent articles however, they portray themselves as equal partners in educating students about plagiarism and promoting academic integrity on campus. Though Auer and Krupar (2001) suggest that "librarians are in a unique position to help prevent and detect plagiarism by forming partnerships with faculty to re-examine assignments and instructional sessions and by informing them of Internet paper mills and useful search strategies" (p. 415), they also emphasise that "librarians must now actively seek out new roles on campus that will create open and regular dialogues with students about information and its ethical use" (p. 424). It appears that plagiarism is one area where there is consensus on campus about the need for education. And, as Lampert (2004) aptly points out, just as responsibility for dealing with academic offences is often shared between faculty, administrators, student service officers, and librarians, the responsibility for educating students about the ethical use of information should also be shared.

We believe this shift from a reactive to proactive role has been brought about by the combination of the emergence of information literacy standards and the growing awareness of an academic integrity crisis in higher education. Indeed, according to Arp and Woodard's (2002) informal survey of their colleagues, the development of information literacy standards and "the rise of plagiarism, questions of copyright and social and ethical use of information" (p.125) number among the top five most significant issues facing information literacy librarians in 2000. Standard Five of the Association of College and Research Libraries' Information Literacy Competency Standards for Higher Education (Association of College and Research Libraries [ACRL], 2004) which deals with the ethical use of information, represents a significant addition to the competencies outlined in the American Library Association's [ALA] 
1989 Presidential Committee on Information Literacy: Final Report. Both documents define information literacy as a set of abilities "to recognize when information is needed" and "...to locate, evaluate and use effectively the needed information" (ALA, 1989, p.3; ACRL, 2004, p.2). The ability to "understand the economic, legal and social issues surrounding the use of information, and access and use information ethically and legally" (ACRL, p. 3) represents a significant addition to the competencies outlined in the Final Report and, in our opinion, speaks to the widespread use of the Web and the incidence of cyberplagiarism, that is, "student copying from the many online Web sites" (Lathrop \& Foss, 2000. p.18) as an issue of grave concern in higher education. ${ }^{3}$ As Arp and Wood (2002) point out,

it's not surprising that the topics of plagiarism and copyright have emerged as significant questions in the last five years when the now common use of computers and the Web is considered. Technology has blurred the once clearly delineated and separate processes of the use of information and its creation. Cutting, pasting, and cropping are simple keystrokes. The knowledge of when these actions are appropriate or inappropriate is less easily imparted. (p. 130)

In addition to information literacy standards and awareness, a second reason for this shift in role may be due to the availability of services such as Turnitin which have relieved librarians of the task of verifying matching text, allowing them to adopt a more proactive role in deterring plagiarism and promoting academic integrity. In an article about Hofstra University's subscription to Turnitin -which she personally initiated and the subsequent decrease in plagiarism on campus, librarian Margaret Burke states: "Of course we are pleased with this decline and we feel that it is the consequence of our using Turnitin coupled with the more active stance assumed by Axinn Library librarians" (Burke, 2004, section 4, p. 8). Our review of the literature did not indicate whether librarians or automated services such as Turnitin are more effective at detecting plagiarism, although we suspect that Turnitin may serve as a stronger deterrent.

Instructional strategies used by librarians to promote academic integrity and deter plagiarism include modeling the ethical use of information (Wood, 2004), discussion of plagiarism and academic integrity in library workshops (Auer \& Krupar, 2001; Burke, 2004; Lampert, 2004; Wood, 2004), teaching students how to do research (Burke, 2004; Oliphant, 2002) and cite sources, creating print and online citation style guides and tutorials (Auer \& Krupar; Harrison, 2004; Lampert, 2003; Stubbings \& Brine, 2003; Wood, 2003), and linking to reputable plagiarism deterrence and detection websites (Harrison, 2004; Stubbings \& Brine, 2003). Wood suggests a blended information literacy academic integrity model for librarians based on a six-point strategy that includes "balancing the use of detection software with preventative behaviors such as honest discussions during instructional sessions and reference interviews" (p. 240). This strategy is also used in classes at Hofstra University, during which librarians inform students about how Turnitin works (Burke, 2004). Lampert's model for incorporating anti-plagiarism instruction into the disciplines includes investigating what plagiarism means within the disciplinary context, becoming familiar with citation styles, communicating professional codes of ethics, identifying disciplinary or professional associations that focus on ethics, and making appropriate instructional resources available to assist students in the study of information ethics (2004).

In terms of collaborative activities, both Lampert (2004) and Wood (2004) provide examples of how to integrate instruction on the ethical use of information and on deterring plagiarism in student-centered classroom activities. Librarians may also play a role in assisting faculty in the redesign of assignments to prevent plagiarism (Auer \& Krupar, 2001; Wood, 2004). One area where librarians do not agree on strategy however, is how to address students' use of the Web to complete their academic 
assignments. While some believe teaching effective use of the Web and how to evaluate and cite websites are the best ways to address the problem of cyberplagiarism (Arnold \& Jayne, 1998; Auer \& Krupar; Lampert, 2004; Wood, 2004), others believe the Web should be addressed only after students have been taught how to use the authoritative, peer-reviewed sources available from the libraries (Burke, 2004).

\section{Goal of the study}

In this study we sought to examine the role of librarians in promoting academic integrity and in educating students and faculty about the ethical use of information at Canadian research-intensive universities using text-matching software.

There are currently 92 universities in Canada (Association of Universities and Colleges of Canada, 2004). The top 10 research universities, calculated according to a combination of the number of Ph.D. degrees and peer-reviewed federal grants awarded, are referred to as the 'G10'. ${ }^{4}$ Since G10 universities are comparable to McGill in terms of their mission, size and structure, we limited our sample to the seven English member institutions that currently subscribe to or use text-matching software in at least one department. In all cases, the software being used was Turnitin. Of the universities surveyed, the following six returned questionnaires completed with usable data:

- McGill University

- McMaster University

- University of Alberta

- University of British Columbia

- University of Toronto

- University of Western Ontario ${ }^{5}$

\section{Methods}

The purpose of the research was exploratory: we sought to gather information on current practices of academic librarians. Information was obtained from the sample group via two methods: observation and questionnaire. An experience survey, used to gather and synthesise the experiences of practitioners in a particular field (Powell \& Connaway, 2004), was employed for data collection.

For the observation, institutional websites, particularly sections dealing with the library and academic integrity, were thoroughly investigated for details about current policies, promotion and instructional activity relating to academic integrity. Site maps were consulted to identify institutional bodies responsible for academic integrity. When the site map was not helpful, the website's search engine was used to search for terms such as 'academic integrity', 'academic dishonesty', 'plagiarism', and 'Turnitin'. Library webpages were searched for information on instruction, information literacy, plagiarism prevention and Turnitin.

The websites were also helpful in identifying possible respondents for the questionnaire. These individuals were then contacted in February 2005 by telephone to explain the aim of the study and to confirm their willingness to participate. In some cases, a more appropriate contact person to complete the questionnaire was identified. In all cases, the actual questionnaire respondent was confirmed by one of the researchers via telephone the week before the questionnaire was distributed. All respondents were employees of the respective institutions and were considered informed on the involvement of librarians in promoting academic integrity, according to verbal self-report. 
Kibler's (1993, p.8) "[f]ramework for addressing academic dishonesty from a student development perspective" was used as a basis to develop the survey questions. This framework, designed to help institutions of higher education to assess their ethos, policies and programs from a student development perspective has been, and continues to be used at McGill University as a self-assessment tool. Sample questions from Kibler's framework were selected, adapted if necessary, and grouped into three sections for the survey: 'Academic Integrity Policies and Procedures', 'Promotion of Academic Integrity', and 'Instruction Related to Academic Integrity'. Questions about the role of the library were added to each of these sections. An additional section, focusing solely on the role of the library in promoting academic integrity, which does not appear in Kibler's framework, was added. These questions were developed based on common practices identified in the literature review and our own experience.

The questionnaire was delivered electronically with SurveyMonkey.com ${ }^{6}$, a wellknown and reliable online survey tool that allows monitoring of respondents and aggregating data for easy reporting of results. The questionnaire was composed of a total of 45 questions about information in four areas: policy, promotion, education, and library involvement. It took approximately 10 minutes to complete and included opportunities to add comments or clarifications to answers. The electronic survey was administered in late February 2005.

\section{Results}

\section{Academic integrity policies and procedures}

The first section consisted of a total of seven questions dealing with university policies regarding academic integrity, the use of subscription text-matching software, and the monitoring of academic integrity by a formal university body. The results of these questions are listed in Table 1.

\section{Table 1. Academic Integrity Policies and Procedures}

\begin{tabular}{|c|c|c|c|c|}
\hline Existing policies and procedures & Yes & No & $\begin{array}{l}\text { Don't } \\
\text { Know }\end{array}$ & $\begin{array}{l}\text { No } \\
\text { Response }\end{array}$ \\
\hline $\begin{array}{l}\text { (a) Academic integrity policies and procedures distributed } \\
\text { to all students }\end{array}$ & 2 & 1 & 3 & 0 \\
\hline $\begin{array}{l}\text { (b) Academic integrity policies and procedures state and } \\
\text { define prohibited behaviors }\end{array}$ & 6 & 0 & 0 & 0 \\
\hline $\begin{array}{l}\text { (c) Academic integrity policies and procedures state con- } \\
\text { sequences for engaging in prohibited behaviors }\end{array}$ & 6 & 0 & 0 & 0 \\
\hline $\begin{array}{l}\text { (d) Academic integrity policies and procedures describe } \\
\text { student and faculty responsibilities }\end{array}$ & 5 & 0 & 1 & 0 \\
\hline $\begin{array}{l}\text { (e) University policy regarding use of text-matching soft- } \\
\text { ware }\end{array}$ & 5 & 1 & 0 & 0 \\
\hline (f) Institutional subscription to text-matching software & 4 & 1 & 1 & 0 \\
\hline $\begin{array}{l}\text { (g) Formal university body responsible for monitoring aca- } \\
\text { demic integrity }\end{array}$ & 3 & 2 & 1 & 0 \\
\hline (h) Librarian is a member of this university body & 1 & 2 & 1 & 1 \\
\hline
\end{tabular}

When asked if their university had a policy regarding the use of text-matching software such as Turnitin (e), 5 of the 6 respondents answered yes, with the remaining respondent answering 'no'. When asked if their institution currently 
subscribed to such a service (f), two respondents answered, "don't know" and "no", respectively. Given our pre-selection of these seven institutions based on observation that each had at least a limited subscription to Turnitin, this would appear contradictory. These responses could indicate that the licensing agreement was currently under negotiation or that the librarian was unaware of the use of Turnitin on campus. Regarding the existence of a formal university body for monitoring academic integrity $(\mathrm{g})$, of the three respondents that indicated that such a group exists, one answered that a librarian was currently a member of such a group.

\section{Promotion of academic integrity}

The second section of the survey dealt with the promotion of academic integrity at the university and librarian involvement in this activity. Questions focused on the discussion of academic integrity in campus orientations for new students, new faculty, new librarians and teaching assistants, as well as on the inclusion of information about policies in publications and other materials. The results of these questions are listed in Table 2.

\section{Table 2. Promotion of academic integrity}

\begin{tabular}{|c|c|c|c|}
\hline Promotional activities & Yes & No & $\begin{array}{l}\text { Don't } \\
\text { Know }\end{array}$ \\
\hline \multicolumn{4}{|l|}{ Discussion of academic integrity included in: } \\
\hline orientation for new students & 2 & 1 & 3 \\
\hline orientation for graduate students and teaching assistants & 3 & 0 & 3 \\
\hline training for new faculty & 3 & 0 & 3 \\
\hline training for new librarians & 3 & 3 & 0 \\
\hline first meeting of every academic course & 4 & 0 & 2 \\
\hline \multicolumn{4}{|l|}{ University documentation about academic integrity includes: } \\
\hline a definition of academic integrity & 6 & 0 & 0 \\
\hline that plagiarism is prohibited and reasons why & 6 & 0 & 0 \\
\hline a statement of students' responsibilities & 6 & 0 & 0 \\
\hline \multicolumn{4}{|l|}{ Announcements about academic integrity: } \\
\hline on campus (e.g., press, posters, mailing lists) & 3 & 2 & 1 \\
\hline in the library (e.g., publications, websites, or handouts) & 2 & 3 & 1 \\
\hline
\end{tabular}

\section{Academic integrity education}

Seventeen questions examined the role of librarians in academic integrity education. These results are summarised in Tables 3 and 4. Upon examination of these results, it is clear that all of the respondents offer some form of instruction about the ethical use of information. Given the overlap between academic integrity and information literacy education, this result was not surprising. In terms of what each of the categories represents, it is possible that there could be some blurring between the categories. The following comments regarding instruction were indicative of the inclusion of academic integrity principles in library-offered instruction:

When there is a requirement in a specific course that plagiarism detecting software be used, Information Literacy sessions facilitated for the course will include information about using it. 
Responsible use of information is typically always included in IL [information literacy] sessions.

Library maintains a comprehensive website on plagiarism, cyberplagiarism, and academic integrity.

Librarians teach sessions in whole or in part on cyberplagiarism, citation guides, how to structure assignments (for faculty), how to research papers (for students), and bibliographic management software.

Table 3. Type of instruction offered relating to academic integrity

\begin{tabular}{|l|c|c|}
\hline & \multicolumn{2}{|c|}{ Department } \\
\hline Type of instruction & Library & $\begin{array}{c}\text { Other } \\
\text { campus } \\
\text { body }\end{array}$ \\
\hline Academic integrity presentation or discussion & 2 & 3 \\
When to include a citation & 4 & 3 \\
Guidelines for citation styles & 5 & 3 \\
How to manage bibliographic references using software & 5 & 2 \\
Managing online information sources using bookmarking tools such as & 1 & 1 \\
FURL, Onfolio, or Pluck & & 0 \\
Other & 1 & \\
\hline
\end{tabular}

Table 4. Formats of library instruction relating to academic integrity

\begin{tabular}{|l|c|c|c|}
\hline & Yes & No & $\begin{array}{c}\text { Don't } \\
\text { Know }\end{array}$ \\
\hline In credit courses & 3 & 1 & 2 \\
In library workshops & 4 & 0 & 2 \\
Online & 2 & 1 & 3 \\
Elsewhere & 1 & 2 & 3 \\
\hline
\end{tabular}

Role of the librarian in promoting academic integrity through collaboration

The findings for questions about the role of the library in promoting academic integrity support common practices described in the literature. As indicated above, few librarians continue to participate in verifying suspected cases of plagiarism. The most widespread type of collaboration is between librarians and the campus teaching service. Results are summarised in Table 5. The following comments related to these questions indicate that many collaborative links are already in existence:

I think librarians would be happy to help professors design better assignments but I don't know if any are actually doing this at the moment.

The Teaching and Learning Centre is part of a collaborative partnership with the Library. 
Have worked in the past with the Writing Centre and the Centre for Teaching and Academic Growth (Faculty development) on creation of resources for students and faculty. Will do more in future.

Workshops on promoting academic integrity through course design are offered [by librarians] as part of the Teaching and Learning Services' Course Design and Teaching workshops.

We hope to work collaboratively in the future.

We present a workshop for the Teaching Assistant Training Programme on supporting undergraduate research. In this workshop, one of the topics we touch on is plagiarism, why students do it, and strategies to prevent it. We also present a workshop for the Office of Teaching Advancement for Faculty on similar themes.

Table 5. Role of the Librarian in Promoting Academic Integrity through Collaboration

\begin{tabular}{|l|c|c|c|}
\hline At least one librarian participates in: & Yes & No & $\begin{array}{c}\text { Don't } \\
\text { Know }\end{array}$ \\
\hline Disciplinary committees & 1 & 4 & 1 \\
Verifying suspected cases of plagiarism & 0 & 5 & 1 \\
Academic skills training for offenders & 0 & 6 & 0 \\
Assisting in the design of assignments to deter plagiarism & 4 & 0 & 2 \\
$\begin{array}{l}\text { Collaborating with campus teaching and learning services to pro- } \\
\text { mote academic integrity }\end{array}$ & 5 & 1 & 0 \\
\hline
\end{tabular}

\section{Conclusion}

Given that our sample was purposive and extremely limited, results are not necessarily representative of academic integrity policies and educational efforts at Canadian institutions of higher education; nor can they be generalised. What they do indicate however, is that librarians at the universities surveyed are actively involved in promoting academic integrity and deterring plagiarism. Discussions of academic integrity and the ethical use of information are included in library workshops and library instructional materials at most institutions. Not surprisingly, the most commonly offered type of library instruction is citation style guidelines. Areas for further development include announcements about academic integrity in library promotional materials, academic integrity presentations in credit courses, and the creation of online tutorials. In terms of campus collaboration, four of the six librarians surveyed assist faculty in designing assignments to deter plagiarism, but only two of the six give in-class presentations on academic integrity. This is an area which merits greater outreach and collaboration. Since results suggest that the most common form of campus partnership occurs through the teaching and learning services unit, as librarians continue to work with faculty in this forum, it is hoped that new opportunities for collaboration within the disciplines and within the classroom will arise.

\section{Endnotes}

${ }^{1}$ Turnitin is a registered trademark of iParadigms, LLC, "a California company that provides a service to universities, colleges and other educational institutions to assist in the prevention of plagiarism". For more information, see their website: http:// www.turnitin.com 
${ }^{2}$ Paper mill "is a term used to describe an Internet Web site that students can access in order to obtain a paper on any topic [...] Paper mills generally fall into one of three broad categories: free; for-a-fee for an existing paper; custom written. Today one is most likely to find sites that combine the features of the three distinct types" (Cvetkovic, 2004).

${ }^{3}$ While not all Canadian universities are members of ACRL, the ACRL Standards are the most commonly used in Canadian universities as Canada does not have its own Standards.

${ }^{4}$ Since this survey was conducted, three more universities joined the group to make what is now the G13.

${ }^{5}$ Université Laval and Université de Montréal, the two French-language G10 universities, do not use Turnitin because the documents it indexes are primarily, if not exclusively, English. As a result, these institutions were excluded from the survey.

${ }^{6}$ SurveyMonkey.com is an online subscription-based tool for creating and managing web surveys. It is available from http://www.surveymonkey.com.

${ }^{7}$ For more information on these social bookmarking tools, see http:// www.furl.net/; http://www.onfolio.com/; http://www.pluck.com/.

\section{Authors' biographies}

Lorie Kloda is the instructional technology librarian at the McGill University Life Sciences Library where she coordinates information literacy instruction in the Faculties of Medicine and Dentistry for students, staff and clinicians. She has worked in a hospital library, a patient information centre, a research centre and a public library. Currently enrolled in doctoral studies at McGill School of Information Studies, Lorie is researching the information behaviour of rehabilitation therapists. In addition to academic integrity, her other interests include the teaching of evidence-based practice and consumer health information.

Karen Nicholson is Information Literacy Coordinator, Humanities and Social Sciences Library, and Liaison Librarian, McGill University Library. She coordinates library orientation programs across campus and is a member of McGill's Academic Integrity Subcommittee. Her interests include information literacy, academic integrity and integrating library resources into course management systems such as WebCT Vista.

\section{References}

American Librarian Association (1989). Presidential committee on information literacy: Final Report. Retrieved 30 March 2005 from http://www.ala.org/ala/acrl/ acrlpubs/whitepapers/presidential.htm

Arnold, J. M. \& Jayne, E. A. (1998). Dangling by a slender thread: The lessons and implications of teaching the World Wide Web to freshmen. Journal of Academic Librarianship, 24, 43-52.

Arp, L. \& Woodard, B. S. (2002). Recent trends in information literacy and instruction. Reference \& User Services Quarterly, 42, 124-132.

Association of College and Research Libraries. (2004). Objectives for information literacy instruction: A model statement for academic librarians. Retrieved 30 March 2005 from http://www.ala.org/ala/acrl/acrlissues/acrlinfolit/ infolitstandards/standardstoolkit.htm

Association of Universities and Colleges of Canada (2004). Canadian universities. Association of Universities and Colleges of Canada. Retrieved 30 March 2005 from http://www.aucc.ca/can uni/general info/overview e.html

Auer, N. J. \& Krupar, E. M. (2001). Mouse click plagiarism: The role of technology in plagiarism and the librarian's role in combating it. Library Trends, 49, 415-432.

Brown, L. (2004). Toronto teen wins battle against McGill University over plagiarismdetector. Canadian Press Newswire,16 January. 
Burke, M. (2004). Deterring plagiarism: A new role for librarians. Library Philosophy and Practice, 6. Retrieved 30 March 2005 from http:// www.webpages.uidaho.edu/ mbolin/burke.htm

Churchill, L. (2004, November 4). Turnitin.com debated. McGill Daily 94(7) [online]. Retrieved 30 March 2005 from http://www.mcgilldaily.com/viewphp?aid=3120

Cvetkovic, N. (2004). The dark side of the Web: Where to go to buy a paper. In V. Bowman, (Ed.). The Plagiarism Plague: A Resource Guide and CD-ROM Tutorial for Educators and Librarians (pp.25-26). New York: Neal-Schuman.

Goel, V. (2002). Academic integrity and the deterrence and detection of plagiarism [Memorandum]. Retrieved 30 March 2005 from http://www.provost.utoronto.ca/ English/Academic-Integrity-and-the-Deterrence-and-Detection-ofPlagiarism.html

Harrison, T. (2004). Plagiarism and the academic library: A look around the region. Bulletin of the Atlantic Provinces Library Association, 67, 1-4.

Kibler, W. H. (1993). A framework for addressing academic dishonesty from a student development perspective. NASPA Journal, 31(1), 8-18.

Lampert, L. D. (2004). Integrating discipline-based anti-plagiarism instruction into the information literacy curriculum. Reference Services Review, 32, 347-355.

Lathrop, A. \& Foss, K. (2000). Student Cheating and Plagiarism in the Internet Era: A Wake-Up Call. Englewood, Co: Libraries Unlimited.

Oliphant, T. (2002). Cyber-plagiarism: Plagiarism in a digital world. Feliciter 48(2), 7880.

Ontario Universities Conference on Academic Integrity. (n.d.). Retrieved 17 September 2006 from http://www.yorku.ca/yfile/archive/index.asp?Article=1695

Powell, R. R. \& Connaway, L. S. (2004). Basic Research Methods forLibrarians. (4th ed.) Westport, Conn.: Libraries Unlimited.

Roszak, T. (2004). Raging against the machine. Los Angeles Times, 28 January, p. B13.

Sokoloff, H. (2003). One in three students admits to plagiarizing: Linked to teacher's skill. National Post, 30 August, p. A6.

Stubbings, R. \& Brine, A. (2003). Plagiarism and the role of the library. Library \& Information Update, 2, 42-44.

Wahl, N. (2002).. Online database pinpoints plagiarism. Instructors must inform students before web site to detect cheaters. News@UofT [online] 21 November. Retrieved 30 March 2005 from http:// www.newsandevents.utoronto.ca/bin3/021121a.asp

Wood, G. (2004). Academic original sin: Plagiarism, the internet, and librarians. Journal of Academic Librarianship, 30, 237-242. 